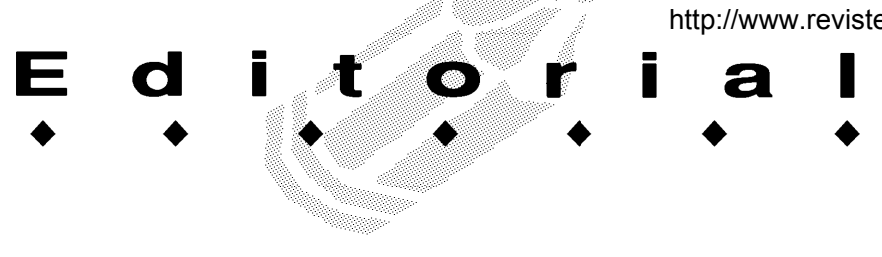

\title{
OBLIGATS A BEURE AL GALET: UNS GRAUS DE MESTRE SENSE ARGUMENTS
}

L'anomenat procés de Bolonya -potser seria millor anomenar-lo el despropòsit organitzatiu de Bolonya- va posant cadascú al seu lloc, tot $\mathrm{i}$ que entre la majoria del professorat no hi ha hagut gens de debat, gens. Amb un debat serè i lliure, amb càmeres, i sense necessitat d'especialistes o pseudoespecialistes, segurament haurien sortit qüestions d'envergadura, que haurien proporcionat elements de reflexió, de canvi, de millora, aspectes que, òbviament, qualsevol professor no pot ni vol negligir. És d'aquesta qüestió que volem parlar i no pas d'altres que han sortit en el despropòsit, segurament tan o més important que aquesta.

La imposició d'alguns ha irromput en escena, i ha donat les pautes del que s'ha de fer, com s'ha de fer i quan s'haurà de fer. Aquesta imposició manifesta ha encrespat els ànims de molts universitaris, del tot sensibles a la millora, que ho han verbalitzat o deixat fer amb la intenció de no ser massa contaminats per parauletes sense tremp. No s'ha acceptat la pedagogia que traspua, per la forma com s'ha presentat -a diàleg zero-, per la utilització d'una terminologia genèrica que sembla més dedicada a aparentar que a fomentar millores concretes i fonamentalment per l'escassa potència quant a valoració de la ciència i del coneixement establert que s'observa en les noves propostes.

A las facultats de Ciències de l'Educació el procés de formació de mestres ha patit en alguns casos la imposició de la qual parlem. Han aplicat terra cremada als futurs graus de Mestre. Així, amb aquest bagatge no han aconseguit engrescar ni els que estan a tocar, cosa que ja és dir: àvids de protagonisme s'han mig cruspit el bloc de la formació bàsica, i quant al contingut propi de les Didàctiques específiques, han procurat diluir-lo, com ja és habitual, amb una perspectica aparentment nove- dosa però que en realitat no aporta res de nou.

Podent fer un pla de mestre per al segle XXI s'ha passat a un pla poc pensat, impositiu en molts aspectes. Per no mirar enrere ni s'ha mirat el Pla Professional de la República, no pas per copiar-lo, ja que no tocava, sinó per veure-hi les línies mestres d'actuació. No! Amb aquest canvi de pla, les disciplines pedagògiques pretenen convertir-se -tant en el grau d'educació infantil com en el d'educació primària-en el pal de paller de les dues titulacions. El grau d'educació infantil ha de preparar mestres per a l'etapa 0-6 i el grau de primària per a la de 6-12. A les dues titulacions es necessita més que mai una reflexió aprofundida de les diverses disciplines que hi incideixen. El nostre sistema escolar sap prou bé que la ciència que han de donar els futurs mestres no és si la llum entra a l'aula per la dreta o per l'esquerra, sinó saber com treballar les matemàtiques a l'escola, com treballar la llengua o com iniciar el pensament científic, la qual cosa implica dominar la ciència referent i saber com guiar la progressió constant dels alumnes.

Entenem que a partir d'una filosofia que acceptem, el desplegament impositiu segurament no hi ajudarà. Al darrer editorial d'aquesta mateixa revista dèiem que "preparar mestres implica formar ciutadans per ser l'avançada, i creiem que aquesta funció no pot deixar-se a expenses d'un voluntarisme i de falsos discursos sobre el que s'ha de fer sense fer-ho, sense un nord clar". Convenim, per tant, que a les Didàctiques específiques no se les ha tingut en compte. Les pressions han estat excessives, des d'autoritats de la universitat a algun departament àvid de protagonisme. La línia torta d'ara serà difícil d'adreçar: malauradament seguirà ben torta. Mentre, alguns seguiran mirant en una altra direcció. 